\title{
Patterns of ichthyofaunal diversity and distribution across Jebba Hydro-Electric Power (HEP) dam, Jebba, north-central Nigeria
}

\author{
S. O. Oladipo ${ }^{a b * \# ~(D), ~ L . ~ M . ~ N n e j i c * \# ~(D), ~ O . ~ A . ~ I y i o l a ~}{ }^{b}$, I. C. Nneji ${ }^{d}$, A. O. Ayoola ${ }^{c}$ (D), \\ K. M. Adelakun e,f, A. T. Anifowoshe ${ }^{b, g}$, A. C. Adeola (D) and M. K. Mustapha ${ }^{b}$ \\ aZoology Unit, Department of Biosciences and Biotechnology, Kwara State University, Malete, Kwara State, Nigeria \\ ${ }^{b}$ Department of Zoology, Faculty of Life Sciences, University of Ilorin, Ilorin, Kwara State, Nigeria \\ ${ }^{c}$ Kunming Institute of Zoology, Chinese Academy of Sciences, 650223, Kunming, China \\ ${ }^{\mathrm{d} D e p a r t m e n t ~ o f ~ B i o l o g i c a l ~ S c i e n c e s, ~ U n i v e r s i t y ~ o f ~ A b u j a, ~ A b u j a, ~ N i g e r i a ~}$ \\ ${ }^{\mathrm{e}}$ Federal College of Wildlife Management, New Bussa, Nigeria \\ ${ }^{\mathrm{f} F}$ orestry Research Institute of Nigeria, Jericho Hill, Ibadan, Nigeria \\ gDepartment of Molecular Reproduction, Development and Genetics, Indian Institute of Science Bangalore, India \\ *e-mail: olayinka_sgn@yahoo.co.uk; lotannanneji@gmail.com \\ "Equal contribution/first authorship
}

Received: April 22, 2019 - Accepted: November 27, 2019 - Distributed: May 31, 2021

(With 2 figures)

\begin{abstract}
The ichthyofauna diversity of the Jebba Hydroelectric Power (HEP) Dam, Jebba, North-central Nigeria was studied. Fishes were sampled for 24 months using gill net, hook and line, and cast net. Individuals were identified using morphological and molecular (mitochondrial Cytochrome c Oxidase subunit I) data. A total of 9605 freshwater fishes were recorded during the sampling period. The use of an integrative taxonomic approach enabled the identification of 83 species belonging to 42 genera. Additionally, the study recorded three unidentified species - Ctenopoma sp, Malapterurus sp., and Protopterus sp. Analyses showed that individuals belonging to families Cichlidae and Mochokidae dominated the dam. The diversity analyses revealed relatively high fish diversity during the rainy season at the downstream section of Jebba HEP dam compared to the upstream section. The study, therefore, showed the presence of a diverse fish community comprising high species richness and diversity across the Jebba HEP dam. Finally, we recommend proper biodiversity monitoring and assessment of freshwater fish diversity across Nigeria. In addition, the use of an integrated taxonomic approach is recommended for appropriate species' identification and studies of freshwater fishes from Nigeria.
\end{abstract}

Keywords: diversity, fisheries management, DNA barcoding, Nigeria.

\section{Padrões de diversidade e distribuição da ictiofauna na barragem de hidroelétricas (HEP) de Jebba, Jebba, Nigéria norte-central}

\begin{abstract}
Resumo
A diversidade da ictiofauna da hidrelétrica de Jebba (HEP), Jebba, centro-norte da Nigéria foi estudada. Os peixes foram amostrados por 24 meses, utilizando rede de emalhar, anzol e linha, e rede de arrasto. Os indivíduos foram identificados usando a abordagem combinada morfológica e molecular (citocromo c Oxidase mitocondrial subunidade I). Um total de 9605 peixes de água doce foram registrados durante o período de amostragem. A identificação das espécies utilizando a abordagem taxonômica integrada possibilitou a identificação de 83 espécies pertencentes a 42 gêneros. Além disso, o estudo registrou três espécies não identificadas - Ctenopoma sp, Malapterurus sp e Protopterus sp. Análises mostraram que indivíduos pertencentes às famílias Cichlidae e Mochokidae dominaram a barragem. As análises dos índices de diversidade revelaram uma diversidade de peixes relativamente alta durante a estação chuvosa na seção a jusante da barragem Jebba HEP em comparação com a seção a montante. O estudo mostrou, portanto, a presença de diversas comunidades de peixes, que incluem alta riqueza e diversidade de espécies através da barragem Jebba HEP. Finalmente, recomendamos o monitoramento adequado da biodiversidade e a avaliação da diversidade de peixes de água doce em toda a Nigéria. Além disso, recomenda-se o uso de abordagem taxonômica integrada para a identificação adequada das espécies e estudos de peixes de água doce da Nigéria.
\end{abstract}

Palavras-chave: diversidade, gestão pesqueira, DNA barcoding, Nigéria. 


\section{Introduction}

Nigerian freshwater ecosystem spans over 14 million hectares (FDF, 2008). Amongst its freshwater ecosystem is the Niger River, with its tributaries extending across the country (Olaosebikan and Raji, 1998). Over the years, several development projects have been constructed on this river. Notable among them is the construction of hydro-electric power (HEP) plants, which led to the development of the Jebba HEP dam. The Jebba HEP dam extends from Jebba to the southern Kainji dam with tributaries stretching across Awun, Eku, Moshi, and Oli rivers. It has good potential for the fish catch with an estimate of 909-1818 tons/annum (Adelakun et al., 2017).

Although Jebba HEP dam was constructed to improve the populace standard of living, increased rate of anthropogenic activities poses threats to the aquatic ecosystem as well as the biotic community (Oladipo et al., 2018a). This has led to habitat destruction and, ultimately, the disruption of spatio-temporal pattern of water discharge. Overexploitation, continuous, and indiscriminate fish harvest, and pollution are also common challenges to fishery resources in the area (Oladipo et al., 2018a). The resultant effects of these threats could lead to a reduction in population size, and fish landed trawl, and loss of gene pool (Poff and Allan, 1995; Meldgaard et al., 2003; Odo et al., 2009; Aliko et al.,
2010). Thus, a critical survey of its ichthyofaunal diversity is important for an improved management plan for the fishery resources and its associated habitat.

Most studies on the Jebba HEP dam have focused exclusively on the upstream section of the dam (KLRI, 1983; Ita et al., 1983, 1984). To date, comprehensive information on the diversity and distribution of freshwater fishes is lacking. Hence, there is a need for an exhaustive inventory of the ichthyofaunal diversity of both up and downstream sections of the dam. Herein, a complete inventory of the fish diversity of the Jebba HEP dam was provided. The objectives of our study are to (1) present a comprehensive checklist of freshwater fishes in the Jebba HEP dam, and (2) compare the patterns of species abundance and distribution across seasons and localities. This study provides baseline information on fish diversity, abundance, and distribution within the Jebba HEP dam. Further, we discussed the environmental challenges affecting the ichthyofauna of the Jebba HEP dam.

\section{Material and Methods}

\subsection{Study area}

The Jebba HEP dam lies within the middle belt region of Nigeria between longitude $4^{\circ} 34^{\prime} 12^{\prime \prime}-4^{\circ} 43^{\prime} 48^{\prime \prime} \mathrm{E}$ and latitude $9^{\circ} 10^{\prime}-9^{\circ} 55^{\prime} \mathrm{N}$ (Figure 1). The dam falls within the

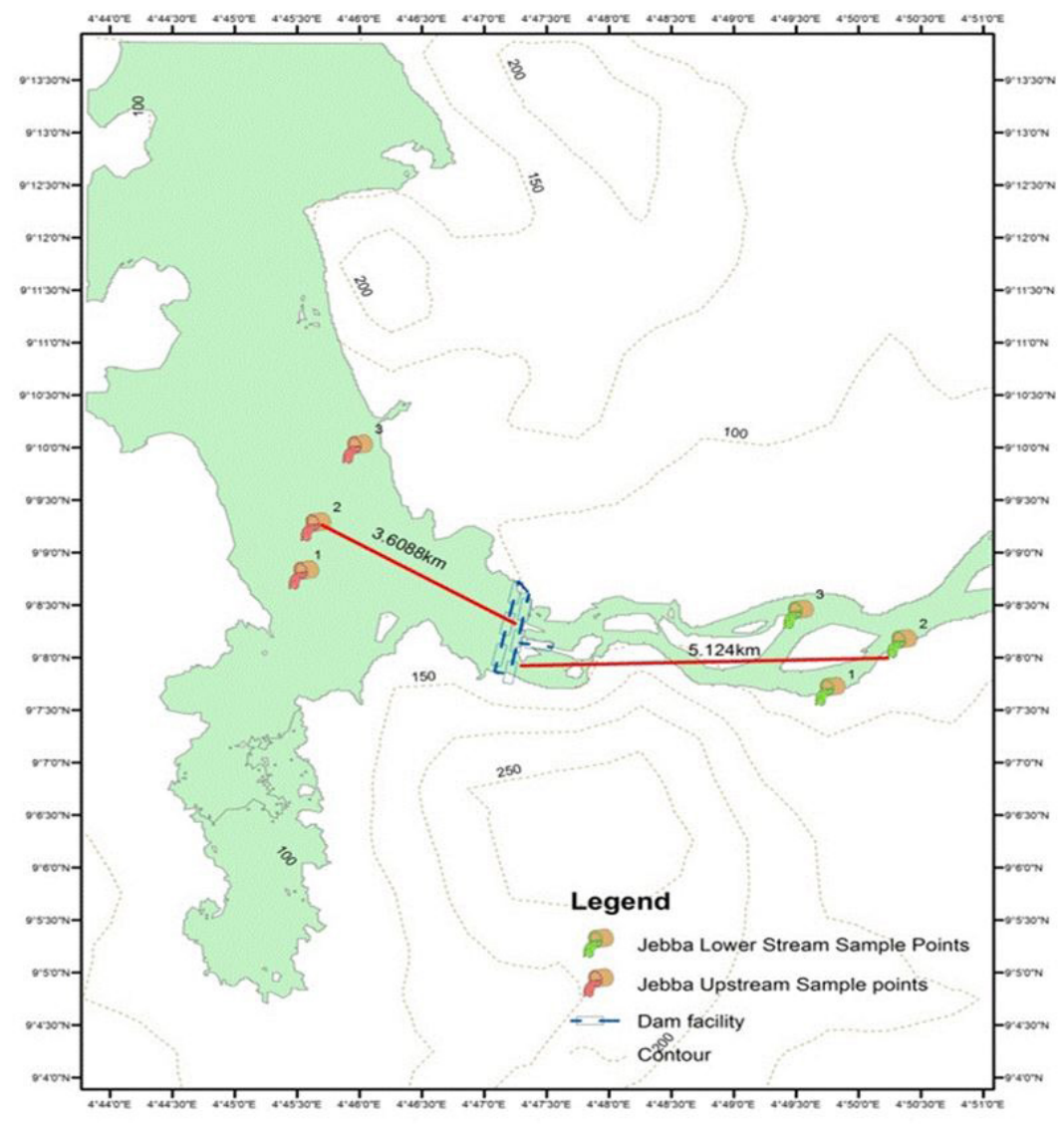

Figure 1. Map showing different sampling points within Jebba Hydro-Electric Power, North-central Nigeria. 
Guinea savanna eco-region of Nigeria and is characterized mainly with two seasons: dry (November to March) and rainy (April to October) seasons (Adelakun et al., 2017). The total annual rainfall ranges between 1270-1524 mm, with the highest rainfall observed in August. Monthly temperature is highest (about $30^{\circ} \mathrm{C}$ ) in March, and lowest (about $25^{\circ} \mathrm{C}$ ) in August (Adelakun et al., 2017). The dam has a total length of $134 \mathrm{~km}$, the maximum width of $24.1 \mathrm{~km}$, mean and maximum depth of $11 \mathrm{~m}$ and $60 \mathrm{~m}$ respectively, the surface area of $1270 \mathrm{~km}^{2}$, a volume of $13 \times 109 \mathrm{~m}^{3}$, and catchment's area of $1.6 \times 106 \mathrm{~km}^{2}$ (Obot, 1989). Our study covered the entire Jebba HEP dam, including the upper (Station 1; Jebba North) and downstream (Station 2; Jebba South) stations of the dam. These stations are notable for fishing and are about $8.7 \mathrm{~km}$ apart.

\subsection{Sample collection and species identification}

Sampling followed ethical approval number UERC/ASN/2017/991 from the University Ethical Review Committee (UERC), University of Ilorin, Nigeria. Fish samples were collected from January 2017 to December 2018 with the help of local fishermen. Fishes were collected using gill nets, hook and line, and cast net. On collection, representative specimens (2-3 individuals per species) were packed in a box containing ice blocks and transported to the Zoology Laboratory of the Department of Bioscience and Biotechnology, Kwara State University (KWASU), Malete, Nigeria. Specimens were identified following the checklist and keys of the fish identification guide by Olaosebikan and Raji (1998), Idodo-Umeh (2003), and the FishBase databases (Froese and Pauly, 2017). Fishes were individually imaged using digital scanning and later deposited in the Museum of the Department of Bioscience and Biotechnology, KWASU, Malete, Nigeria. To carry out the DNA barcoding of individuals with uncertain species-level identification, tissue samples (tail fin) were collected and preserved in 95\% ethanol (Sigma-Aldreich, Germany) and subsequently stored under $-80^{\circ} \mathrm{C}$. Vouchers were fixed with $4 \%$ formalin and kept in $70 \%$ ethanol for long-term storage. Procedures for DNA barcoding for species identification followed the methodology described by Iyiola et al. (2018).

\subsection{Diversity analyses}

Fish species abundance were determined using the following criteria, $\geq 10 \%=$ dominant, $1-9 \%=$ Subdominant, $<1 \%$ (but caught more than once) = Occasional, $<1 \%$ (caught only once) = Rare adopting the formula by Benech et al. (1983). The relative frequency, Simpson's, Shannon-Wiener diversity index, and Margalef's index methods using PAST (Hammer et al., 2001).

\section{Results}

\subsection{Species composition and identification}

A total of 9605 freshwater fish belonging to 83 species, 43 genera, 24 families and 11 orders were recorded and identified using combined morphological and genetic approaches (Table 1). The combined molecular and morphological approach enabled accurate identification of the following to species-level: Auchenoglanis occidentalis

Table 1. Checklist of Freshwater Fishes from Jebba Hydroelectric Power Dam, North-Central Nigeria.

\begin{tabular}{|c|c|c|c|c|c|}
\hline \multirow{2}{*}{ Order } & \multirow{2}{*}{ Family } & \multirow{2}{*}{ Genus } & \multirow{2}{*}{ Species } & \multicolumn{2}{|c|}{ Location } \\
\hline & & & & Up Stream & Down Stream \\
\hline \multirow[t]{9}{*}{ Mormyriformes } & Mormyridae & Heperopisus & Heperopisus bebe & $\mathrm{XXX}$ & $\mathrm{XXX}$ \\
\hline & & Mormyrus & Mormyrus hasselquisti & XX & XX \\
\hline & & & M. rume & XX & XX \\
\hline & & & M. macrothalamus & $\mathrm{X}$ & $\mathrm{X}$ \\
\hline & & & M. anguilloides & XX & XX \\
\hline & & Mormyrops & Mormyrops deliciosus & XX & $\mathrm{XX}$ \\
\hline & & Petrocephalus & Gnathonemus cyprynoides & $\mathrm{X}$ & $\mathrm{X}$ \\
\hline & & & Marcusenius senegalensis & $\mathrm{X}$ & $\mathrm{X}$ \\
\hline & Gymnarchidae & Gymnarchus & Gymnarchus niloticus & $\mathrm{X}$ & $\mathrm{X}$ \\
\hline \multirow[t]{10}{*}{ Characiformes } & Characidae & Hydrocynus & Hydrocynus forskalli & XXX & XXX \\
\hline & & & Hydrocynus vittatus & XXX & XXX \\
\hline & & Alestes & Alestes baremose & XX & XXX \\
\hline & & & A. dentex & XX & XX \\
\hline & & Brycinus & Brycinus nurse & $\mathrm{XXX}$ & XXX \\
\hline & & & B. intermedius & & $\mathrm{X}$ \\
\hline & & Miralestes & Miralestes occidentalis & & $\mathrm{X}$ \\
\hline & Dischodontidae & Distichodus & Distichodus rostratus & XX & XX \\
\hline & & & Distichodus encyphalus & $\mathrm{X}$ & $\mathrm{X}$ \\
\hline & Citharinidae & Citharinus & Citharinus citharus & $\mathrm{XXX}$ & XXX \\
\hline Cypriniformes & Cyprinidae & Labeo & Labeo senegalensis & XX & XXX \\
\hline
\end{tabular}

Key: Abundance: XXX, Common; XX, Occasional; X, Rare. 
Table 1. Contined...

\begin{tabular}{|c|c|c|c|c|c|}
\hline \multirow{2}{*}{ Order } & \multirow{2}{*}{ Family } & \multirow{2}{*}{ Genus } & \multirow{2}{*}{ Species } & \multicolumn{2}{|c|}{ Location } \\
\hline & & & & Up Stream & Down Stream \\
\hline & & & Labeo branchypoma & $\mathrm{X}$ & \\
\hline & & & L. cubie & XX & $\mathrm{XXX}$ \\
\hline & & Barbus & Barbus callipterus & $\mathrm{X}$ & $\mathrm{X}$ \\
\hline & & & B. occidentalis & XXX & $\mathrm{XXX}$ \\
\hline & & & B. lagoensis & $\mathrm{X}$ & \\
\hline & & Leptocypris & Leptocypris & $\mathrm{X}$ & $\mathrm{X}$ \\
\hline & & Garra & Garra waterloti & & $\mathrm{X}$ \\
\hline & & Raimas & Raimas Senegalensis & & $\mathrm{X}$ \\
\hline \multirow[t]{38}{*}{ Siluriformes } & Bagridae & Bagrus & Bagrus filamentosus & $\mathrm{XXX}$ & $\mathrm{XX}$ \\
\hline & & & B. docmac & XXX & $\mathrm{XXX}$ \\
\hline & & & B. bayad & $\mathrm{XX}$ & $\mathrm{XX}$ \\
\hline & Clariidae & Clarias & Clarias geriepinus & $\mathrm{X}$ & $\mathrm{X}$ \\
\hline & & & C. anugularis & $\mathrm{X}$ & $\mathrm{X}$ \\
\hline & & & C. camerunensis & $\mathrm{X}$ & $\mathrm{X}$ \\
\hline & & & C. lazera & $\mathrm{X}$ & \\
\hline & Malapteruridae & Malapterurus & Malapterurus electricus & $\mathrm{X}$ & $\mathrm{X}$ \\
\hline & Schilbeidae & Schilbe & Schilbe mystus & $\mathrm{X}$ & $\mathrm{XX}$ \\
\hline & & & S. intermedius & $\mathrm{XXX}$ & $\mathrm{XXX}$ \\
\hline & & & S. uranoscopus & XX & $\mathrm{XX}$ \\
\hline & & Parailia & Parailia pelucida & & $\mathrm{X}$ \\
\hline & Claroteidae & Achenoglanis & Achenoglanis bisculatatus & $\mathrm{XXX}$ & XXX \\
\hline & & & A. occidentalis & $\mathrm{XXX}$ & $\mathrm{XXX}$ \\
\hline & & Clarotes & Clarotes laticeps & $\mathrm{XXX}$ & $\mathrm{XXX}$ \\
\hline & & Chrysichthys & Chrysichthys auratus & $\mathrm{XX}$ & $\mathrm{X}$ \\
\hline & & & C. nigrodigitatus & XX & $\mathrm{XX}$ \\
\hline & & & C. filamentous & $\mathrm{X}$ & $X$ \\
\hline & & & Chrisichthys walkeri & $\mathrm{X}$ & $\mathrm{X}$ \\
\hline & Ariidae & Arius & Arius heudeloti & $\mathrm{X}$ & $\mathrm{XX}$ \\
\hline & & & A. gigas & $\mathrm{X}$ & X \\
\hline & Mockokidae & Brysynodontis & Brysynodontis bensoda & $\mathrm{XX}$ & $\mathrm{XXX}$ \\
\hline & & Hemisynodontis & $\begin{array}{l}\text { Hemisynodontis } \\
\text { membranaceus }\end{array}$ & $\mathrm{XX}$ & $\mathrm{XXX}$ \\
\hline & & Synodontis & Synodontis budgetti & $\mathrm{XXX}$ & $\mathrm{XXX}$ \\
\hline & & & S. gambiansis & XXX & $\mathrm{XXX}$ \\
\hline & & & S. eupterus & X & XXX \\
\hline & & & S. violaceus & XXX & XXX \\
\hline & & & S. schall & XXX & XXX \\
\hline & & & S. clarias & $\mathrm{XX}$ & $\mathrm{XXX}$ \\
\hline & & & S. occelifer & $\mathrm{X}$ & $\mathrm{X}$ \\
\hline & & & S. vemiculatus & & $\mathrm{XX}$ \\
\hline & & & S. clarias & $\mathrm{X}$ & XX \\
\hline & & & S. omias & $\mathrm{XX}$ & $\mathrm{XXX}$ \\
\hline & & & S. resupinatus & $\mathrm{XX}$ & $\mathrm{XX}$ \\
\hline & & & S. sorex & & $\mathrm{X}$ \\
\hline & & & S. thomasi & & $\mathrm{X}$ \\
\hline & & & S. filamentosus & $\mathrm{X}$ & $\mathrm{X}$ \\
\hline & & Chiloglanis & Chiloglanis batesii & & $\mathrm{X}$ \\
\hline \multirow[t]{2}{*}{ Perciformes } & Centropomidae & lates & Lates niloticus & XXX & XXX \\
\hline & Cichlidae & Oreochromis & Oreochromis niloticus & $\mathrm{XXX}$ & $\mathrm{XXX}$ \\
\hline
\end{tabular}

Key: Abundance: XXX, Common; XX, Occasional; X, Rare. 
Table 1. Contined...

\begin{tabular}{|c|c|c|c|c|c|}
\hline \multirow{2}{*}{ Order } & \multirow{2}{*}{ Family } & \multirow{2}{*}{ Genus } & \multirow{2}{*}{ Species } & \multicolumn{2}{|c|}{ Location } \\
\hline & & & & Up Stream & Down Stream \\
\hline & & & Oreochromis aureus & $\mathrm{XX}$ & $\mathrm{X}$ \\
\hline & & Tillapia & Tillapia zilli & XXX & $\mathrm{XX}$ \\
\hline & & & T. guinensis & $\mathrm{XXX}$ & $\mathrm{X}$ \\
\hline & & & T. dagetti & $\mathrm{XXX}$ & $\mathrm{XX}$ \\
\hline & & Sarotherodon & Sarotherodon galileaus & XXX & $\mathrm{XX}$ \\
\hline & & & S. macrocephalus & XXX & XX \\
\hline & & Hemichromis & Hemichromis bimaculatus & $\mathrm{X}$ & $X$ \\
\hline & & Chromidotillapia & Chromidotillapia guntheri & $\mathrm{X}$ & \\
\hline & Anabatidae & Ctenopoma & Ctenopoma kingsleyae & & $X$ \\
\hline & Channidae & Parachanna & Parachanna obscura & & $X$ \\
\hline Tetraodontiformes & Tetraodontidae & Tetraodon & Tetraodon lineatus & $X$ & $\mathrm{X}$ \\
\hline Lepidosireniformes & Protopteruridae & Protopterus & Protopterus annectans & & $\mathrm{X}$ \\
\hline Osteoglossidae & Osteoglossidae & Heterotis & Heterotis niloticus & & $X$ \\
\hline & Notopteridae & Xynomystus & Xynomystus nigri & & X \\
\hline Rajiformes & Dasyatidae & Dasyatis & Dasyatis garouaensis & & X \\
\hline Polypteriformes & Polypteridae & Polypterus & $\begin{array}{l}\text { Polypterus senegalus } \\
\text { senegalus }\end{array}$ & & $\mathrm{X}$ \\
\hline Clupeiformes & Clupeidae & Laeviscutella & Laeviscutella dekimpel & & $\mathrm{X}$ \\
\hline
\end{tabular}

Key: Abundance: XXX, Common; XX, Occasional; X, Rare.

(Cuvier and Valenciennes, 1840), Bagrus bajad (Forskal, 1775), Bagrus docmac (Forskal, 1775), Brienomyrus niger (Günther, 1866), Citharinus citharus (Geoffrey, 1809), Clarias gariepinus (Burchell, 1822), Clarotes laticeps (Ruppel, 1829), Distichodius rostratus (Gunther, 1864), Gymnarchus niloticus (Cuvier, 1829), Hemichromis bimaculatus (Gill, 1862), Heterotis niloticus (Cuvier, 1829), Hydrocynus vittatus (Boulenger, 1898), Labeo senegalensis (Cuvier and Valenciennes, 1842), Lates niloticus (Linnaeus, 1758), Mormyrops anguilloides (Linnaeus, 1758), Mormyrus macrophthalmus (Gunther, 1866), Sarotherodon galilaeus (Linnaeus, 1758), Parachana obscura (Gunther, 1861), Schilbe mystus (Linnaeus, 1758), Synodontis clarias (Linnaeus, 1758), Synodontis membranacea (Geofrey, 1809), Synodontis nigrita (Cuvier and Valenciennes, 1864), Synodontis obesus (Boulenger, 1898), Tetraodon lineatus (Linnaeus, 1758), Coptodon zillii (Gervals, 1848), Malapterurus electricus (Gmeli, 1789), Polypterus senegalus (Cuvier, 1829), and Xynomystus nigri (Gunther, 1868).

Individuals morphologically identified as Chrysichthys nigrodigitatus (Lacepede, 1803), Oreochromis aureus (Steindachner, 1864), Synodontis schall (Bloch and Schneide, 1801) and Protopterus annectens (Owen, 1839) clustered with Chrysichthys sp, Sarotherodon galilaeus, Synodontis aff. bastiani, Protopterus sp respectively (Appendix A of the supplementary material), following this, we changed the species' names as Chrysichthys sp, Sarotherodon galilaeus, Synodontis aff. bastiani, Protopterus sp pending further identification. Further, individuals identified as Ctenopoma sp, Malapterurus sp, and Protopterus sp could not be assigned to species-level using both morphology and genetic data (Appendix A of the supplementary material), thus, referred to genera. Further, we observed that individuals morphologically identified as Dasyatis garouaensis (Stauch and Blanc, 1962) showed a similarity match of $83.10 \%$ with Dasyatis microps (India) (Appendix A of the supplementary material). Given the unavailability of sequences for Dasyatis garouaensis, our species identification could be taken as tentative, pending further revision.

\subsection{Variation in species composition}

Family Mochokidae had the highest number of species (number of species $(n)=17$ ) and fish catch (Number of fish catch $(N)=2439$; Relative Frequency $(r)=25.40 \%$; Appendix B of the supplementary material). Low fish catch $(\mathrm{N}=1)$ and relatively lower frequency of occurrence $(\mathrm{r}=0.01 \%)$ were recorded for family Anabantidae, Dasyatidae, Notopteridae and Protopteruridae. Moderate population density and frequencies were recorded for other families (Table $1 \&$ Appendix B of the supplementary material) including Characidae $(\mathrm{N}=1050 ; \mathrm{r}=10.93 \%)$, Claroteidae $(\mathrm{N}=914 ; \mathrm{r}=9.57 \%)$, Cyprinidae $(\mathrm{N}=$ $678 ; \mathrm{r}=7.06 \%)$, Citharinidae $(\mathrm{N}=592 ; \mathrm{r}=6.16 \%)$, Mormyridae $(\mathrm{N}=519 ; \mathrm{r}=5.40 \%)$, Bagridae $(\mathrm{N}=447 ; \mathrm{r}=4.65 \%)$, Dischodontidae $(\mathrm{N}=356 ; \mathrm{r}=3.71 \%)$, Schilbeidae $(\mathrm{N}=327 ; \mathrm{r}=3.40 \%)$, Cetropomidae $(\mathrm{N}=302 ; \mathrm{r}=3.14 \%)$, Ariidae $(\mathrm{N}=98 ; \mathrm{r}=1.02 \%)$, Clariidae ( $\mathrm{N}=49 ; \mathrm{r}=0.51 \%)$, Gymnarcidae $(\mathrm{N}=36 ; \mathrm{r}=0.38 \%)$, Tetraodontidae $(\mathrm{N}=23 ; \mathrm{r}=0.24 \%)$, Malapteruridae $(\mathrm{N}=8 ; \mathrm{r}=0.08 \%)$, Polypteruridae $(\mathrm{N}=6 ; \mathrm{r}=0.06 \%)$, Osteoglossidae $(\mathrm{N}=4 ; \mathrm{r}=0.04 \%)$ and Clupeidae $(\mathrm{N}=3 ; \mathrm{r}=0.03 \%)$.

In addition, fewer number of species $(n=1)$ were recorded for families - Gymnarcidae, Citharinidae, Malapteruridae, Centropomidae, Channidae, Tetraodontidae, Protopteruridae, Osteoglossidae, Dasyatidae, Anabantidae, Notopteridae, Polypteridae and Clupeidae (Table 1). Other families 
were represented by modest number of species as follows: Cyprinidae $(n=9)$, Ciclidae $(n=8)$, Mormyridae $(n=8)$, Characidae $(n=7)$, Claroteidae $(n=7)$, Schilbeidae $(n=4)$, Clariidae $(n=4)$, Bagridae $(n=3)$, Dischodontidae $(n=2)$; and Ariidae $(\mathrm{n}=2)$ (Table1).

\subsection{Overall patterns of species distribution and abundance across sampling stations}

Generally, high fish catch frequency was recorded at the upstream $(\mathrm{N}=5075)$ compared to the downstream $(\mathrm{N}=4530)$. The family Cichlidae dominated the upstream $(\mathrm{N}=1379)$, while Mochokidae dominated the downstream $(\mathrm{N}=1823)$. Upstream, we recorded high fish catch for O. niloticus $(\mathrm{N}=375)$, T. zilli $(\mathrm{N}=309)$, S. galileaus $(\mathrm{N}=141)$, O. aureus $(\mathrm{N}=69)$, L. niloticus $(\mathrm{N}=219)$, A. bisculatatus $(\mathrm{N}=209)$, B. filamentosus $(\mathrm{N}=106)$, B. docmac $(\mathrm{N}=133)$, C. citharus $(\mathrm{N}=405)$ and $D$. rostratus $(\mathrm{N}=114)$ (Table 1$)$. Downstream, higher frequency of occurrence were recorded for $B$. bensoda $(\mathrm{N}=267), H$. membranaceus $(\mathrm{N}=252)$, S. budgetti $(\mathrm{N}=157)$, S. eupterus $(\mathrm{N}=134), S$. schall $(\mathrm{N}=226)$ and $H$. vittatus $(\mathrm{N}=118)$ (Appendix B of the supplementary material). While three (3) species (L. branchypoma, B. lagoensis and $C$. lazera) were restricted upstream, 16 species were found only downstream of Jebba HEP dam - B. intermedius,
M. occidentalis, G. waterloti, R. senegalensis, P. pelucida, $S$. vemiculatus, S. sorex, S. thomasi, C. batesii, P. annectans, $H$. niloticus, D. garouaensis, X. nigri, C. kingsleyae, P. senegalus senegalus and L. dekimpel (Table 1).

\subsection{Patterns of distribution across seasons}

During rainy reason, we observed high fish catch $(\mathrm{N}=2434$; $\mathrm{r}=25.34 \%$ ) from downstream section compared to upstream $(\mathrm{N}=2387 ; \mathrm{r}=24.85 \%$ ) (Appendix B of the supplementary material). Comparatively, we recorded relatively higher fish catch from upstream $(\mathrm{N}=4688 ; \mathrm{r}=27.99)$ during the dry season compared to downstream $(\mathrm{N}=2096$; $\mathrm{r}=$ $21.82)$. Out of 83 species captured, 61 species ( $r=97.60 \%)$ were common to both dry and rainy season. However, a total of 62 species $(r=97.88 \%)$ were recorded during the dry season, while 82 species $(r=99.74 \%)$ were recorded during the rainy season (Appendix B of the supplementary material) from the Jebba HEP dam. During the dry season, an equal number of species $(n=47)$ were observed at the upstream and downstream sections of the dam. However, during the wet season, we recorded 59 and 79 fish species at the upstream and downstream sections, respectively.

The diversity analyses (Table 2 and Figure 2) showed a significantly higher level of diversity during the rainy

Table 2. Diversity Indices for the Seasonal Distribution of Freshwater Fishes from the Jebba Hydroelectric Power Dam, North-central Nigeria.

\begin{tabular}{|c|c|c|c|c|}
\hline \multirow{2}{*}{ Indices } & \multicolumn{2}{|c|}{ Dry Season } & \multicolumn{2}{|c|}{ Rainy Season } \\
\hline & Upstream & Downstream & Upstream & Downstream \\
\hline Taxa_S & 47 & 49 & 59 & 79 \\
\hline Individuals & 2688 & 2096 & 2387 & 2434 \\
\hline Dominance_D & 0.04375 & 0.0439 & 0.038 & 0.02401 \\
\hline Simpson_1-D & 0.9562 & 0.9561 & 0.962 & 0.976 \\
\hline Shannon_H & 3.368 & 3.374 & 3.583 & 3.948 \\
\hline Evenness_e^ $\mathrm{e}^{\wedge} \mathrm{H} / \mathrm{S}$ & 0.6174 & 0.5957 & 0.6097 & 0.6731 \\
\hline Margalef & 5.814 & 6.264 & 7.473 & 9.732 \\
\hline
\end{tabular}

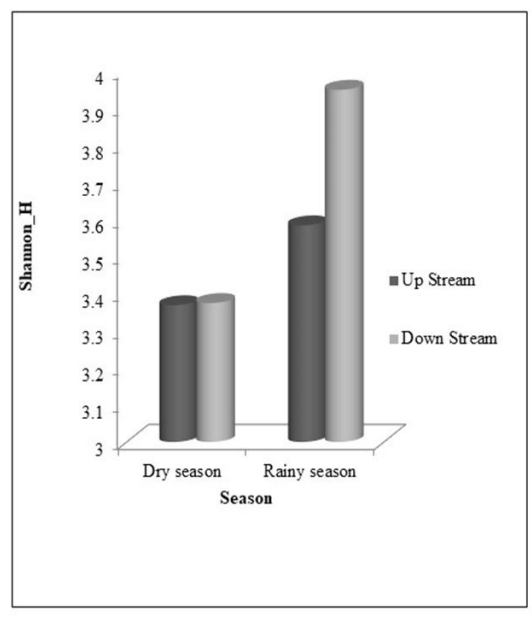

A

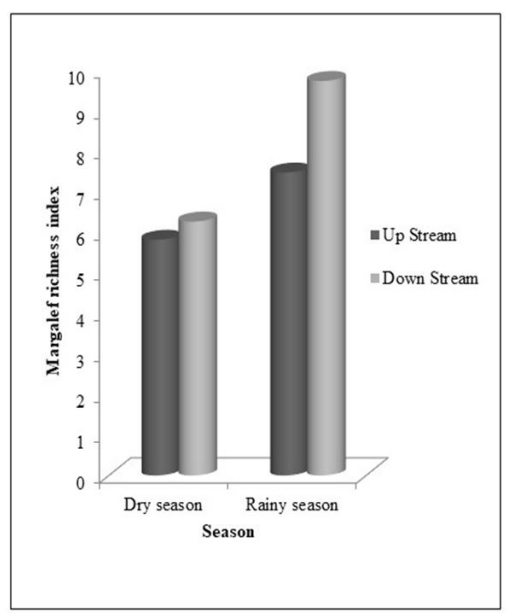

B

Figure 2. (A) Shannon-Weiner and (B) Margelef's richness indices showing seasonal changes in fish species richness and diversity in the Jebba Hydro-Electric Power, North-central Nigeria. 
season at the downstream compared to the upstream section. At the upstream, high species diversity in rainy season (Margalef $=7.47 ; \mathrm{H}=3.58 ; 1-\mathrm{D}=0.96$ ) was recorded compared to the dry season (Margalef $=5.81 ; \mathrm{H}=3.37$; $1-\mathrm{D}=0.96$ ) (Table 2). Similarly, at the downstream, high species diversity was recorded during the rainy season (Margalef $=9.73 ; \mathrm{H}=3.95 ; 1-\mathrm{D}=0.98$ ) compared to dry season $($ Margalef $=6.26 ; \mathrm{H}=3.37 ; 1-\mathrm{D}=0.96)$ (Table 2).

\section{Discussion}

A total of 83 fish species belonging to 24 families recorded in this study presents a more comprehensive inventory of ichthyofauna of the Jebba HEP dam when compared with previous studies (e.g., Ita et al., 1983; Ita, 1993). This current record was higher when compared to 51 species (12 families) recorded by Abiodun and Odunze (2011). The present study benefits from having broader coverage and a more comprehensive sampling across the Jebba HEP dam than the other studies and, thus, it marks the beginning of a better understanding of ichthyofaunal diversity and distribution across the Jebba HEP dam. In addition, most of the fish species recorded in this present study have been reported to be present in Nigerian inland waters (Ita et al., 1983, 1984, 1985; Akinyemi et al., 1986; Ita, 1993; Olaosebikan and Raji, 1998; Sikoki et al., 1998; Abiodun and Odunze, 2011; Allison and Okadi, 2013; Oguntade et al., 2014; Oladipo et al., 2018b; Mustapha, 2010). Also, the use of combined morphological and molecular approaches enabled us to unravel species identity as well as discover possible potential new species (Ctenopoma sp, Malapterurus $\mathrm{sp}$ and Protopterus sp) from the area. Studies involving combined molecular, morphological, and ecological data are needed to ascertain if these species represent new species or sub-species for the area.

In comparison, species diversity $(n=83)$ recorded in our work was higher compared to other freshwater bodies in Nigeria such as Asa river ( $\mathrm{n}=21$; Omotosho, 1997), Alau Lake (Idowu and Eyo, 2005), Anambra basin ( $\mathrm{n}=52$; Odo et al., 2009); Oyun reservoir ( $\mathrm{n}=18$; Mustapha, 2010); Usuma reservoir ( $\mathrm{n}=11$; Ataguba et al., 2014) and Apodu reservoir ( $\mathrm{n}=17$; Oladipo et al., 2018b). The observation made on species dominance was lower compared to other Nigerian water bodies e.g., Eko-Ende and Owalla reservoirs (Taiwo, 2010), Majidun Creek (Lawson et al., 2013) and coastal waters of Ondo State (Bolarinwa et al., 2015). The differences in the observed species diversity could be attributed to the size of the river, locations of sampling, the time frame of sampling, and the combination of sampling nets. Our study, with its wider coverage, enabled recovery of fish species that would otherwise remain undetected if sampled within a limited time frame and season.

Of interest to our study are the families Cichlidae and Mochokidae. Similar to previous studies on the Nigerian freshwater ecosystem (Ita and Balogun, 1982; Balogun, 2005; Owolabi, 2008), high species diversities for families Cichlidae $(\mathrm{N}=1754)$ and Mochokidae $(\mathrm{N}=2439)$ were observed. Cichlids have been known to dominate dams in the Nigerian freshwater ecosystem (Mustapha, 2010). Besides, Mochokids have been reported to be abundant in the Jebba HEP dam (Ita, 1978; Ita and Balogun, 1982; Balogun, 2005). Similarly, Cichlidae and Mochokidae have been known to be present in high abundance in the lower River Niger basin (Oyewo, 2005; Atile et al., 2016; Abiodun and John, 2017). The dominance of these families could be in relation to their prolific breeding capabilities and high adaptation to varying environmental conditions (Mustapha, 2010; Araoye, 1999).

The diversity analyses revealed high species richness and diversity at the downstream section of the Jebba HEP dam, although all sampling localities had a high level of fish species richness. This implies that environmental conditions at the downstream section were conducive for species to thrive and reproduce effectively. In addition, the diversity indices revealed higher number of species and frequency of occurrence both in rainy and dry seasons. The result, therefore, showed Jebba HEP dam represents an important area with good potentials for fisheries and aquaculture.

In conclusion, this present study shows that Jebba HEP dam comprises a high number of fish diversity that faces challenges due to the unregulated fishing gear and poor conservation techniques. These challenges could be attributed to a low level of conservation awareness among the fishermen, inappropriate fishing laws, and lack of adequate fishing regulations in the community. Hence, the implementation of effective fishing regulations, as well as community-based conservation awareness in the area, are necessitated. For instance, conservation awareness geared towards educating the local community on the need for proper management and controlled fishing in the area will improve the understanding of the fishermen on the need for sustainable fishing activities. Finally, this study has provided vital information on the biodiversity of freshwater fishes in the Jebba HEP dam and Nigeria as a whole.

\section{Acknowledgments}

The study was funded by the Federal Government of Nigeria through TETFUND and Kwara State University, Malete. The authors thank the management of Mainstream Energy Solution for approving the fieldwork, Mrs. Roseline Adeshike Oladipo (Interpreter and field assistant) and Jebba artisanal fishermen, for their support during the field survey.

\section{References}

ABIODUN, J.A. and JOHN, P., 2017. Biodiversity and abundance of fish and some processing methods in Lower Niger River, Idah, Kogi State, Nigeria. Nigeria Journal of Fisheries and Aquaculture, vol. 5 , no. 2, pp. 20-25.

ABIODUN, J.A. and ODUNZE, F.C., 2011. Fish composition of Jebba Lake, Nigeria. Nigerian Journal of Fisheries and Aquaculture, vol. 8, no. 2, pp. 284-290. 
ADELAKUN, K.M., MUSTAPHA, M.K., AMALI, R.P. and MOHAMMED, N., 2017. Seasonal variation in nutritional quality of Catfish (Clarias gariepinus) from Upper Jebba Basin, Nigeria. Journal of Nutrition \& Food Sciences, vol. 7, no. 5, pp. 1-4.

AKINYEMI, O., ITA, E.O. and SADO, E.K., 1986. A preliminary assessment of the post impoundment fisheries of Lake Eleiyele and Lake Asejire, Oyo State, Nigeria. New-Bussa: Kainji Lake Research Institute, pp. 44-50. Annual Report.

ALIKO, N.G.G., DA COSTA, K.S., DIETOA, Y.M., OUATTARA, A. and GOURENE, G., 2010. Caractéris-tiques de la population de Distichodus rostratus Günther, 1864 (Pisces: Distichodontidae) du lac de barrage de Taabo (bassin du Bandama, Côte d'Ivoire). Implications pour une gestion rationnelle du stock. Tropicultura, vol. 28 , pp. 50-56.

ALLISON, M.E. and OKADI, D., 2013. Gill net selectivity, seasonal, tidal and photoperiod variation in catch in Lower Nun River, Niger Delta, Nigeria. Scientific Research and Essays, vol. 8, no. 3, pp. 108-114.

ARAOYE, P.A., 1999. Spatio-temporal distribution of the fish Synodontis schall (Teleostei: Mochokidae) in Asa lake, Ilorin, Nigeria. Revista de Biología Tropical, vol. 47, no. 4, pp. 1061-1066.

ATAGUBA, G.A., TACHIA, M.U. and AMINU, G., 2014. Fish species diversity and abundance of Gubi Dam, Bauchi State of Nigeria. Biological Diversity and Conservation, vol. 7, no. 2, pp. 1-9.

ATILE, J.I., SHIMA, J.N. and AKOMBO, P.M., 2016. Food and feeding, length-weight and condition factor of the catfish Synodontis membranaceus (Etiene Geoffroy Saint Hilaire, 1809) (Osteichthyes: Mochokidae) from Lower Benue River, Makurdi, Nigeria. Agriculture. Forestry and Fisheries, vol. 5, no. 4, pp. 87-96. http://dx.doi.org/10.11648/j.aff.20160504.11.

BALOGUN, J.K., 2005. Fish distribution in a small domestic water supply reservoir: a case study of Kangimi Reservoir, Nigeria. Journal of Applied Science \& Environmental Management, vol. 9, no. 1, pp. 93-97.

BENECH, V., DURAND, J.R. and QUENSIERE, J., 1983. Fish communities of lake chad and associated rivers and flood plains. In: J.P. CARMOUZE, J.R. DURAND and C. LÉVÊQUE, eds. Lake Chad: ecology and productivity of a shallow tropic system. The Hague: Dr. W. Junk Publishers, pp. 293-356

BOLARINWA, J.B., FASAKIN, E.A. and FAGBENRO, A.O., 2015. Species composition and diversity of the coastal waters of Ondo State, Nigeria. International Journal of Research in Agriculture and Forestry, vol. 2, no. 3, pp. 51-58.

FEDERAL DEPARTMENT OF FISHERIES - FDF, 2008. Fisheries statistic of Nigeria human population; fish demand and supply in Nigeria, 2000-2015. Lagos: FDF, 56 p.

FROESE, R. and PAULY, D., 2017 [viewed 22 April 2019]. FishBase [online]. Available from: www.fishbase.org

HAMMER, Ø.H., DAVID, A.T. and PAUL, D.R., 2001. PAST: paleontological statistics software package for education and data analysis. Palaeontologia Electronica, vol. 4, no. 1, pp. 4-9.

IDODO-UMEH, G., 2003. Freshwater fishes of Nigeria: taxonomy, ecological notes, diet and utilization. Benin-City, Nigeria: IdodoUmeh Publ., 232 p.

IDOWU, R.T. and EYO, J.E., 2005. Fisheries status and fishing gears of a West African arid zone lake. Animal Research International, vol. 2, no. 2, pp. 353-357.
ITA, E.E., SADO, E.K., BALOGUN, J.K., PANDOGORI, A. and IBITOYE, B., 1985. Inventory survey of Nigerian inland waters and their fishery resources: a preliminary checklist of inland water bodies in Nigeria with special reference to Ponds, Lakes Reservoirs and major Rivers. New-Bussa: Kainji Lake Research Institute. Technical Report Series, no. 14.

ITA, E.O., 1978. Analysis of fish distribution in Kainji Lake, Nigeria. Hydrobiologia, vol. 58, no. 3, pp. 233-244. http://dx.doi. org/10.1007/BF02346958.

ITA, E.O. 1993. Inland fishery resources of Nigeria. Rome: FAO. CIFA Occasional Paper, no. 20.

ITA, E.O. and BALOGUN, J.K., 1982. Report of the preimpoundment fishery survey of Goronyo Reservoir, Sokoto State, Nigeria. Nigeria: Sokoto Rima Basin Development Authority, 86 p.

ITA, E.O., OMORINKOBA, W.S. and BANKOLE, N.O., 1984. Second post-impoundment fishery survey of Jebba Lake. NewBussa: Kainji Lake Research Institute, pp. 62-75. Annual report.

ITA, E.O., OMORINKOBA, W.S., BANKOLE, N.O. and IBITOYE, B., 1983. A preliminary report on the immediate post-impoundment fishery survey of the newly created Jebba Lake, Nigeria. NewBussa: Kainji Lake Research Institute, pp. 67-74. Annual report.

IYIOLA, O.A., NNEJI, L.M., MUSTAPHA, M.K., NZEH, C.G., OLADIPO, S.O., NNEJI, I.C., OKEYOYIN, A.O., NWANI, C.D., UGWUMBA, O.A., UGWUMBA, A.A.A., FATUROTI, E.O., WANG, Y.Y., CHEN, J., WANG, W.Z. and ADEOLA, A.C., 2018. DNA barcoding of economically important freshwater fish species from north-central Nigeria uncovers cryptic diversity. Ecology and Evolution, vol. 8, no. 14, pp. 6932-6951. http:// dx.doi.org/10.1002/ece3.4210. PMid:30073057.

KAINJI LAKE RESEARCH INSTITUTE - KLRI, 1983. Preimpoundment studies of Jebba Lake. New-Bussa: Kainji Lake Research Institute.

LAWSON, E.O., DOSEKU, P.A. and AJEPE, R.G., 2013. Fish assemblage of Majidun Creek, Lagos, Nigeria. The Journal of Biological Sciences, vol. 13, no. 7, pp. 577-586. http://dx.doi. org/10.3923/jbs.2013.577.586.

MELDGAARD, T., NIELSEN, E.E. and LOESCHCKE, V., 2003. Fragmentation by weirs in a riverine system: a study of genetic variation in time and space among populations of European grayling (Thymallus thymallus) in a Danish river system. Conservation Genetics, vol. 4, no. 6, pp. 735-747. http://dx.doi. org/10.1023/B:COGE.0000006115.14106.de.

MUSTAPHA, M.K., 2010. Fish fauna of Oyun reservoir, Offa, Nigeria. Journal of Aquatic Sciences, vol. 25, no. 1, pp. 106-114.

OBOT, E.A., 1989. The macrophytic flora of the draw - down area of Lake Kainji, Nigeria. African Journal of Ecology, vol. 27, pp. 173-177.

ODO, G.K., NWANI, C.D. and EYO, J.E., 2009. The fish fauna of Anambra River Basin, Mageroa Species abundance and morphometry. Revista de Biología Tropical, vol. 57, no. 1-2, pp. 177-186.

OGUNTADE, O.R., OKETOKI, O.T., UKENYE, E.A., USMAN, B.A. and ADELEKE, M.T., 2014. Survey of the present and fast disappearing fish species along two rivers in Niger Delta, Nigeria. $S u$ Ürünleri Dergisi, vol. 9, no. 5, pp. 352-358.

OLADIPO, S.O., MUSTAPHA, M.K., SULEIMAN, L.K. and ANIFOWOSHE, A.T., 2018b. Fish composition and diversity assessment of Apodu Reservoir, Malete, Nigeria. International Journal of Fisheries and Aquatic Studies, vol. 6, no. 2, pp. 89-93. 
OLADIPO, S.O., NNEJI, L.M., ANIFOWOSHE, A.T., NNEJI, I.C., IYIOLA, O.A., ADEOLA, A.C. and MUSTAPHA, M.K., 2018a. Growth pattern and condition factor of seven freshwater fish species from Jebba Lake, north-central Nigeria. Iranian Journal of Ichthyology, vol. 5, no. 2, pp. 167-172.

OLAOSEBIKAN, B.D. and RAJI, A., 1998. Field guide to Nigerian freshwater fishes. New Bussa: Federal College of Freshwater Fisheries Technology.

OMOTOSHO, J.S., 1997. Icththyofauna diversity of Asa reservoir, Ilorin Nigeria. Biosciences, vol. 36, pp. 37-48.

OWOLABI, O.D., 2008. The dietary habits of the upside-down catfish, Synodontis membranaceus (Osteichthyes: Mochokidae) in Jebba lake, Nigeria. International Journal of Tropical Biology, vol. 56, no. 2, pp. 931-936. PMid:19256454.
OYEWO, S.D., 2005. A survey of fish species diversity and abundance in Dogon Ruwa water body of Kamuku National Park, Birnin Gwari, Kaduna State, Nigeria. Zaria: Ahmadu Bello University. M.Sc dissertation.

POFF, N.L. and ALLAN, J.D., 1995. Functional organization of stream fish assemblages in relation to hydrological variability. Ecology, vol. 76, no. 2, pp. 606-627. http://dx.doi.org/10.2307/1941217.

SIKOKI, F.D., HART, A.I. and ABOWEI, J.F.N., 1998. Gill net selectivity and fish abundance in the lower Nun River, Bayelsa State, Nigeria. Journal of Applied Science \& Environmental Management, vol. 1, pp. 13-19.

TAIWO, Y.F., 2010. Fish diversity in two reservoirs in Southwest Nigeria. In: 25th Annual Conference of the Fisheries Society of Nigeria (FISON), 25-29 October 2010, Lagos, Nigeria, pp. 258-265. 


\section{Supplementary Material}

Supplementary material accompanies this paper.

Appendix A: Parts of Neighbor-Joining Trees Used in the identification of some freshwater fishes from Jebba Hydro-Electric Power Dam, North-central Nigeria. (New individuals from Nigeria were labeled as 'unknown specimen' and highlighted with yellow)

Appendix B: Seasonal Distribution of Freshwater Fishes from Jebba Hydroelectric Power Dam, North-central Nigeria. This material is available as part of the online article from http://www.scielo.br/BJB 